\title{
Application of Temperature Stress to Root Zone of Spinach II. Effect of the High Temperature Pre-Treatment on Quality
}

\author{
Yudi CHADIRIN ${ }^{1, *}$, Kota HIDAKA ${ }^{2}$, Yuki SAGO ${ }^{1}$, Takahiro WAJIMA ${ }^{3}$ and Masaharu KITANO \\ ${ }^{\prime}$ Faculty of Agriculture, Kyushu University, Fukuoka 812-8581, Japan \\ ${ }^{2}$ NARO Kyushu Okinawa Agricultural Research Center, National Agriculture and Food Research \\ Organization (NARO), Kurume, Fukuoka, 839-8503, Japan \\ ${ }^{3}$ Faculty of Environmental and Symbiotic Sciences, Prefectural University of Kumamoto, 862-8502, Japan
}

(Received June 18, 2011; Accepted September 26, 2011)

\begin{abstract}
Roots of spinach plants (Spinacia oleracea L.) were exposed to temperature of $10^{\circ} \mathrm{C}, 15^{\circ} \mathrm{C}$ and $30^{\circ} \mathrm{C}$ to induce the effect of the moderate stress with low and high root temperatures, respectively. The excessive growth depression and the consumption of electric energy for the root zone cooling are the main consideration to apply moderately low temperature to roots of spinach for induction of adaptive functions of osmoregulation and antioxidation, where enrichment of healthful substances and reduction of harmful substances were expected. Spinach plants were grown in the soil-less culture system, where the temperature of the nutrient solution in the root zone was set in the four different temperature regimes during two weeks before the harvest (i.e. two weeks $20^{\circ} \mathrm{C}$ with no temperature stresses $\left(20^{\circ} \mathrm{C}\right)$, two weeks $10^{\circ} \mathrm{C}$ with the moderate low temperature stress $\left(10^{\circ} \mathrm{C}\right)$, the first week $30^{\circ} \mathrm{C}$ and the second week $15^{\circ} \mathrm{C}\left(30^{\circ} \mathrm{C} / 15^{\circ} \mathrm{C}\right)$, and the first week $30^{\circ} \mathrm{C}$ and the second week $10^{\circ} \mathrm{C}\left(30^{\circ} \mathrm{C} / 10^{\circ} \mathrm{C}\right)$. Absorption depression in roots and adaptive functions of osmoregulation and antioxidation were induced by the combination of the one week treatment with a moderately high root temperature of $30^{\circ} \mathrm{C}$ and the one week treatment with a moderately low root temperature of $10^{\circ} \mathrm{C}\left(30^{\circ} \mathrm{C} / 10^{\circ} \mathrm{C}\right)$, while the two weeks treatment with a moderately low root temperature of $10^{\circ} \mathrm{C}$ induced no significant adaptive functions of osmoregulation and antioxidation. The treatment of $30^{\circ} \mathrm{C} / 10^{\circ} \mathrm{C}$ only enabled to produce valueadded spinach shoots with high content of healthful substances such as sugars, $\mathrm{Fe}^{2+}$, ASA and SOD and with low content of harmful substances such as $\mathrm{NO}_{3}^{-}$and oxalic acid.
\end{abstract}

Keywords: antioxidation, high temperature pre-treatment, moderately temperature stresses, mountainous and temperate region, osmoregulation, Spinacia oleracea L., valueadded vegetables

\section{INTRODUCTION}

In the root zone of soil-less culture such as hydroponic culture, stress conditions of roots such as low temperature, drought and high salinity can be easily introduced by manipulating conditions of the nutrient solution around roots. These stress conditions in the root zone cause depressions in root absorption which results in osmotic stress and oxidative stress in the plant body. The osmotic

\footnotetext{
Corresponding author: Yudi Chadirin, fax: +81-92-642-2923, e-mail : yudi@bpes.kyushu-u.ac.jp

* Permanent address : Faculty of Agricultural Engineering and Technology, Bogor Agricultural University Campus IPB Darmaga, PO BOX 220, Bogor 16002 Indonesia E-mail: yudi@ipb.ac.id
} 


\section{Y. CHADIRIN ET AL.}

stress and the oxidative stress can induce the plant adaptive function of osmoregulation and anti oxidation. The plant adaptive function can bring advantageous effect such as enrichment in sugar, functional amino acids and antioxidant, and this can be expected to produce high quality and valueadded vegetables and fruits (Kitano et al., 2008). However, the excessive stress brings unfavorable effect such as growth depression caused by decreased water absorption (Fennell and Markhart, 1998; Wan et al., 1999; Hidaka et al., 2008), and delayed flowering (Lokhande et al., 2003).

In the previous study (Hidaka et al., 2008), spinach roots were treated with the low temperature of $5^{\circ} \mathrm{C}$ for two weeks before the harvest, and the adaptive functions of spinach to the low root temperature stress brought the high concentrations on healthful substances (sugar, ascorbic acid and $\left.\mathrm{Fe}^{2+}\right)$ and the low concentration of harmful substances $\left(\mathrm{NO}_{3}^{-}\right.$and oxalic acid). However, the treatment with the low temperature of $5^{\circ} \mathrm{C}$ for two weeks resulted in significant growth depression of the edible part and in excessive consumption of electric energy for the root zone cooling. On the other hand, Tahir et al. (2008) reported that wheat plants grown hydroponically under $23 / 38^{\circ} \mathrm{C}$ (shoot/root temperature) showed high shoot fresh weight compared with those grown under 22/ $22^{\circ} \mathrm{C}$ and $38 / 38^{\circ} \mathrm{C}$. Tsang et al. (1991) reported that plant responded to heat stress and chilling stress by increasing superoxide dismutase (SOD) compounds in different ways. Furthermore, the high temperature treatment of tomato roots for several days changed characteristics of root absorptive functions (Affan et al., 2005). Therefore, to alleviate the unfavorable effects of the excessive low temperature stress to roots, it could be considered that a high temperature pre-treatment of roots followed by a moderate low temperature stress treatment can be one of cooperative option. In this study, the cooperative application of the high temperature pre-treatment to spinach roots was examined to induce favorable effects of the moderate low temperature stress for the soil-less culture of value-added spinach.

\section{MATERIALS AND METHODS}

\section{Plant materials and growth condition}

Spinach plants (Spinacia oleracea L. cv. Orai) were sown in sponge cubes of $2 \times 2 \times 2 \mathrm{~cm}$ in a growth chamber where air temperature was controlled at $20^{\circ} \mathrm{C}$. Ten days after sowing, spinach plants were transplanted to the cultivation beds of a hydroponic system in a greenhouse. The nutrient solution based on the A-prescription of Otsuka House (Otsuka Chemical Co., Ltd., Osaka) with an electrical conductivity $(E C)$ of $3 \mathrm{dS} \mathrm{m}^{-1}$ was circulated from a $60 \mathrm{~L}$ solution tank through the root zone of the spinach at a constant temperature of $20^{\circ} \mathrm{C}$ as the control. The temperature control unit which consists of a water temperature controller with a temperature sensor, a cooler (LPA2, Orion Machinery Co., Ltd., Nagano, Japan) and an electric heater (GEX Co., Ltd,. Osaka, Japan) was installed in the circulation unit, and temperature of the circulating nutrient solution can be controlled to set the root temperature regimes.

\section{High temperature pre-treatment of roots}

In previous study (Hidaka et al., 2008), spinach roots were exposed to the low temperature with $5^{\circ} \mathrm{C}$ for two weeks. However, it is difficult to provide such a low temperature nutrient solution in temperate climate and regions, and it requires a large amount of electric energy to keep the nutrient solution temperature at such low temperature of $5^{\circ} \mathrm{C}$. On the other hand, in mountainous and temperate regions, the temperature of water flowing in the stream varies around $5^{\circ} \mathrm{C}$ during the cold season and around 10 to $15^{\circ} \mathrm{C}$ during the temperate season (i.e. spring and autumn), and this fact suggest that the low temperature stress treatment for roots with a moderately low temperature of $10^{\circ} \mathrm{C}$ or $15^{\circ} \mathrm{C}$ by applying the stream water in mountainous regions can be expected as a sustainable and profitable technology for production of value-added vegetables. Therefore, it was examined to apply the moderate root stress treatment with moderately low root temperatures of $10^{\circ} \mathrm{C}$ and $15^{\circ} \mathrm{C}$ with a cooperative combination of the pre-treatment with a high temperature of the $30^{\circ} \mathrm{C}$. 
The high temperature pre-treatment was introduced before the moderate low temperature stress treatment by changing the temperature of nutrient temperature solution. During two weeks before the harvest, the temperature of the nutrient solution was set in the four different root temperature regimes such as two weeks $20^{\circ} \mathrm{C}$ with no temperature stresses $\left(20^{\circ} \mathrm{C}\right)$, two weeks $10^{\circ} \mathrm{C}$ with the long term low temperature stress by a moderately low temperature $\left(10^{\circ} \mathrm{C}\right)$, the first week $30^{\circ} \mathrm{C}$ and the second week $15^{\circ} \mathrm{C}\left(30^{\circ} \mathrm{C} / 15^{\circ} \mathrm{C}\right)$, and the first week $30^{\circ} \mathrm{C}$ and the second week $10^{\circ} \mathrm{C}\left(30^{\circ} \mathrm{C} /\right.$ $\left.10^{\circ} \mathrm{C}\right)$ (Fig. 1).

\section{Water potential measurements}

Leaves grown under the respective root temperature regimes were sampled at predawn with intervals of two or three days, and water potentials were measured with the psychrometer (Tru Psi, Decagon Devices, Inc., USA) to investigate the expression of osmoregulation. Leaf discs were punched from leaves and water potentials of the respective discs were measured immediately. Furthermore, osmotic potentials were measured on the sampled leaves after rapid freezing and thawing in the ordinary manner, and turgor pressures were evaluated by difference between water potential and osmotic potential. The average values of the respective three plants were used.

Evaluation of harvest quality

Three edible shoots grown under the respective root temperature regimes were sampled with intervals of one week. The respective fresh samples were weighed and thereafter dried in oven at $70^{\circ} \mathrm{C}$ of temperature until reaching a constant weight to determine dry weight and dry matter content of spinach. Total soluble solids content in the shoot of plants were measured by a digital refractometer (PAL-1, Atago Co., Ltd., Tokyo, Japan) and expressed as \% of brix. Concentration of ascorbic acid (ASA), $\mathrm{Fe}^{2+}, \mathrm{NO}_{3}^{-}$and oxalic acid were measured with Reflectometer tests kits/ strips (RQflex 10, Merck Co., Ltd., Germany). Results of ASA, $\mathrm{Fe}^{2+}, \mathrm{NO}_{3}^{-}$and oxalic acid were expressed as mg per $100 \mathrm{~g}$ fresh weight. Activity of superoxide dismutase (SOD) was quantified by using the SOD Assay kit-WST (Dojindo Laboratories, Japan) following the method established by Ukeda (2001). For these measurements, three plants were sampled from different four treatments, and the average values of the respective three plants were used.

\section{RESULTS AND DISCUSSIONS}

Figure 2 shows time courses of water potential, osmotic potential and turgor pressure in leaves of spinach plants treated with the four different root temperature regimes of $20^{\circ} \mathrm{C}, 10^{\circ} \mathrm{C}, 30^{\circ} \mathrm{C} /$ $10^{\circ} \mathrm{C}$ and $30^{\circ} \mathrm{C} / 15^{\circ} \mathrm{C}$ during two weeks before the harvest. Water potential and osmotic potential varied almost in parallel and in the treatments of $30^{\circ} \mathrm{C} / 10^{\circ} \mathrm{C}$ and $30^{\circ} \mathrm{C} / 15^{\circ} \mathrm{C}$, osmotic potential and also water potential dropped after the start of the moderate low temperature stress. Resultantly,

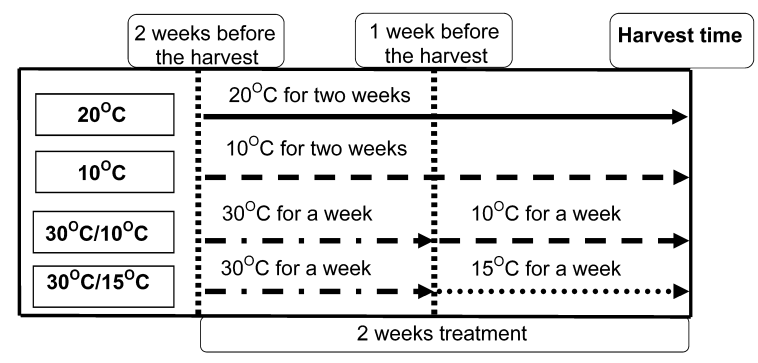

Fig. 1 Schematic diagram of the root temperature treatment. Plants were treated with the four different regimes of root temperature during two weeks before the harvest: $20^{\circ} \mathrm{C}, 20^{\circ} \mathrm{C}$ for two weeks before the harvest; $10^{\circ} \mathrm{C}, 10^{\circ} \mathrm{C}$ for two weeks before the harvest; $30^{\circ} \mathrm{C} / 10^{\circ} \mathrm{C}$, first week $30^{\circ} \mathrm{C}$ and second week $10^{\circ} \mathrm{C} ; 30^{\circ} \mathrm{C} / 15^{\circ} \mathrm{C}$, first week $30^{\circ} \mathrm{C}$ and second week $15^{\circ} \mathrm{C}$. 


\section{Y. CHADIRIN ET AL.}

turgor pressure was kept at a constant of about $0.2 \mathrm{MPa}$ in all the treatments. This indicates that the osmoregulation for maintaining turgor in shoots was induced by the treatment with moderately low root temperatures of $10^{\circ} \mathrm{C}$ and $15^{\circ} \mathrm{C}$ subsequent to the pre-treatment with a high root temperature of $30^{\circ} \mathrm{C}$. Furthermore, in the treatment of $30^{\circ} \mathrm{C} / 10^{\circ} \mathrm{C}$, the osmoregulation was maintained during the second week, and the osmotic potential was remained lower until the harvest.

Figure 3 shows time courses of number of leaves, shoot length, and total leaf area of spinach treated with the four different root temperature regimes of $20^{\circ} \mathrm{C}, 10^{\circ} \mathrm{C}, 30^{\circ} \mathrm{C} / 10^{\circ} \mathrm{C}$ and $30^{\circ} \mathrm{C} / 15^{\circ} \mathrm{C}$ during two weeks before the harvest. During 1 st week, the high root temperature treatment with $30^{\circ} \mathrm{C}$ induced two new leaves to grow out, while no new leaves were induced in the moderately low temperature treatment with $10^{\circ} \mathrm{C}$. During the second week, in the root temperature regime with $10^{\circ} \mathrm{C}$, new leaves grew out more actively, and resultantly the leaf number at the harvest was around 13 in all the temperature regimes. Shoot elongation was depressed a little by the moder-

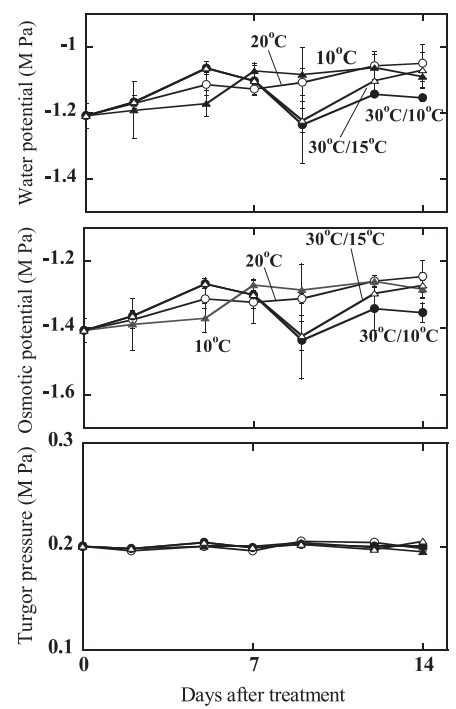

Fig. 2 Time courses of water potential, osmotic potential and turgor pressure in leaves of spinach plants treated with the four different regimes of root temperature during two weeks before the harvest: $\bigcirc$, values under the two weeks $20^{\circ} \mathrm{C}\left(20^{\circ} \mathrm{C}\right)$; values under the two weeks $10^{\circ} \mathrm{C}$ $\left(10^{\circ} \mathrm{C}\right)$; values under the first week $30^{\circ} \mathrm{C}$ and second week $10^{\circ} \mathrm{C}$ $\left(30^{\circ} \mathrm{C} / 10^{\circ} \mathrm{C}\right) ; \triangle$, values under the first week $30^{\circ} \mathrm{C}$ and second week $15^{\circ} \mathrm{C}\left(30^{\circ} \mathrm{C} / 15^{\circ} \mathrm{C}\right)$.
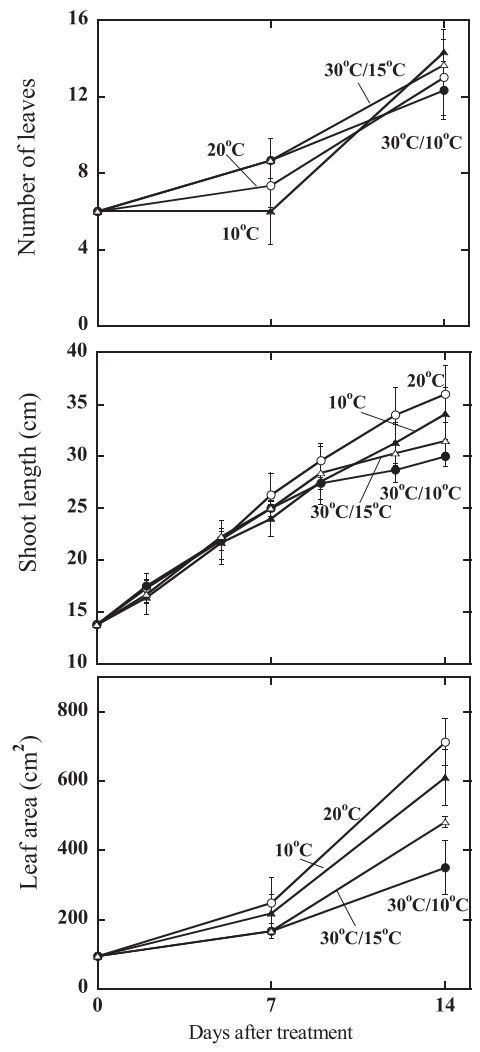

Fig. 3 Time courses of shoot length and leaf area of spinach plants treated with the four different regimes of root temperature during two weeks before the harvesting. Symbols are explained in Fig. 2. 


\section{APPLICATION OF HIGH TEMPERATURE PRE-TREATMENT}

ately low root temperature treatments $\left(10^{\circ} \mathrm{C}\right.$ and $\left.15^{\circ} \mathrm{C}\right)$ subsequent to the pre-treatment with a high root temperature of $30^{\circ} \mathrm{C}$, but there were no large difference in the shoot length at the harvest which distributed around $33 \mathrm{~cm}$ in all the temperature regimes. On the other hand, leaf area was significantly low in the temperature regimes of $30^{\circ} \mathrm{C} / 10^{\circ} \mathrm{C}$ and $30^{\circ} \mathrm{C} / 15^{\circ} \mathrm{C}$, where the high root temperature treatment with $30^{\circ} \mathrm{C}$ in the first week and the moderately low root temperature treatment with $10^{\circ} \mathrm{C}$ and $15^{\circ} \mathrm{C}$ remarkably depressed leaf expansion.

Figure 4 shows time courses of fresh weight, dry weight and dry matter ratio of spinach shoots treated with the four different root temperature regimes of $20^{\circ} \mathrm{C}, 10^{\circ} \mathrm{C}, 30^{\circ} \mathrm{C} / 10^{\circ} \mathrm{C}$ and $30^{\circ} \mathrm{C} / 15^{\circ} \mathrm{C}$ during two weeks before the harvest. Fresh weight and dry weight showed a pattern similar to that found in leaf area (Fig.3), but the depression in dry weight by the low root temperature in the second week appeared smaller than that in fresh weight. Resultantly, the largest dry matter ratio at the harvest was found in the temperature regime of $30^{\circ} \mathrm{C} / 10^{\circ} \mathrm{C}$. This suggests that the depressed increase in dry weight induced by the temperature regime of $30^{\circ} \mathrm{C} / 10^{\circ} \mathrm{C}$ was mitigated a little by osmoregulation accompanied with soluble solids accumulation to leaves.

Figure 5 shows time course of total soluble solids content (brix) in spinach shoots treated with the four different root temperature regimes of $20^{\circ} \mathrm{C}, 10^{\circ} \mathrm{C}, 30^{\circ} \mathrm{C} / 10^{\circ} \mathrm{C}$ and $30^{\circ} \mathrm{C} / 15^{\circ} \mathrm{C}$ during two weeks before the harvest. Brix of shoots can be considered to closely relate to accumulation of
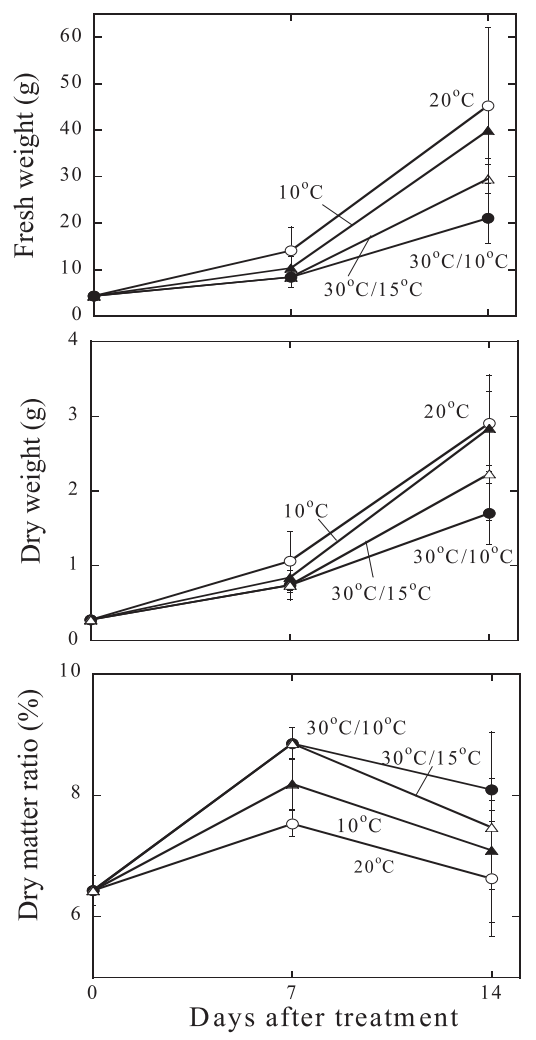

Fig. 4 Time courses of fresh weight, dry weight and dry matter ratio in the shoot of spinach plants treated with the four different regimes of root temperature during two weeks before the harvest. Symbols are explained in Fig. 2.

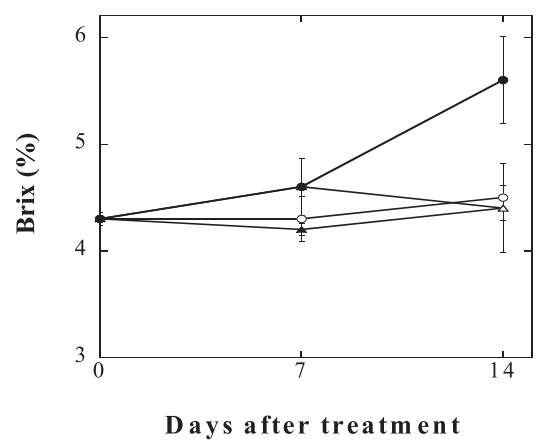

Fig. 5 Time courses of brix in the shoot of spinach plants treated with the four different regimes of root temperature during two weeks before the harvest. Symbols are explained in Fig. 2. 


\section{Y. CHADIRIN ET AL.}

Table 1 Quality of spinach treated with the four different regimes of root temperature during two weeks before the harvest: $20^{\circ} \mathrm{C}, 20^{\circ} \mathrm{C}$ for two weeks before the harvest; $20^{\circ} \mathrm{C}, 10^{\circ} \mathrm{C}$ for two weeks before the harvest; $30^{\circ} \mathrm{C} / 10^{\circ} \mathrm{C}$, first week $30^{\circ} \mathrm{C}$ and second week $10^{\circ} \mathrm{C} ; 30^{\circ} \mathrm{C} / 15^{\circ} \mathrm{C}$, first week $30^{\circ} \mathrm{C}$ and second week $15^{\circ} \mathrm{C}$.

\begin{tabular}{lccccc}
\hline Treatment & $\begin{array}{c}\text { Brix } \\
\%\end{array}$ & $\begin{array}{c}\text { Ascorbic acid (ASA) } \\
\mathrm{mg} / 100 \mathrm{gFW}\end{array}$ & $\begin{array}{c}\text { SOD } \\
10^{3} \mathrm{unit} / \mathrm{gFW}\end{array}$ & $\begin{array}{c}{\left[\mathrm{NO}_{3}^{-}\right]} \\
\mathrm{mg} / 100 \mathrm{gFW}\end{array}$ & $\begin{array}{c}\text { Oxalic acid } \\
\mathrm{mg} / 100 \mathrm{gFW}\end{array}$ \\
\hline $20^{\circ} \mathrm{C}$ & $4.5 \pm 0.1 \mathrm{a}$ & $36.7 \pm 1.6 \mathrm{a}$ & $2.99 \pm 0.39$ & $191.9 \pm 11.3$ & $498.5 \pm 58.7 \mathrm{a}$ \\
$10^{\circ} \mathrm{C}$ & $4.4 \pm 0.4 \mathrm{a}$ & $37.6 \pm 3.4 \mathrm{a}$ & $3.25 \pm 1.68$ & $160.5 \pm 17.9$ & $477.0 \pm 53.3 \mathrm{a}$ \\
$30^{\circ} \mathrm{C} / 10^{\circ} \mathrm{C}$ & $5.6 \pm 0.4 \mathrm{~b}$ & $55.4 \pm 2.6 \mathrm{~b}$ & $6.87 \pm 2.93$ & $82.8 \pm 14.1$ & $124.0 \pm 24.9 \mathrm{~b}$ \\
$30^{\circ} \mathrm{C} / 15^{\circ} \mathrm{C}$ & $4.4 \pm 0.1 \mathrm{a}$ & $36.9 \pm 2.9 \mathrm{a}$ & $4.07 \pm 1.51$ & $146.1 \pm 4.3$ & $361.1 \pm 50.2 \mathrm{~b}$ \\
\hline
\end{tabular}

Values are means of three plants $\pm \mathrm{SD}$. The means followed by the same letter are not significantly different at the 0.05 probability level.

soluble solids enhanced by osmoregulation. Brix in each treatment with root temperature regimes of $20^{\circ} \mathrm{C}, 10^{\circ} \mathrm{C}$ and $30^{\circ} \mathrm{C} / 15^{\circ} \mathrm{C}$ remained almost constant around $4.5 \%$, but in the treatment with a root temperature regime of $30^{\circ} \mathrm{C} / 10^{\circ} \mathrm{C}$, brix at the harvest significantly increased to $5.6 \%$. This suggests that osmoregulation in shoots can be induced by the treatment with the moderately low root temperature of $10^{\circ} \mathrm{C}$ subsequent to the pre-treatment with a high temperature of $30^{\circ} \mathrm{C}$.

Figure 6 shows time courses of concentrations of $\mathrm{Fe}^{2+}$ and ASA and SOD activity in spinach shoots treated with the four different root temperature regimes. Concentrations of $\mathrm{Fe}^{2+}$ and ASA and activity of SOD can be considered to be measures of expression of plant adaptive functions responding to environmental stresses, and these values were significantly increased only in the treatment with a root temperature regime of $30^{\circ} \mathrm{C} / 10^{\circ} \mathrm{C}$. Asada (1999) reported that the environmental stress accelerates the production of active oxygen species such as singlet oxygen $\left({ }^{1} \mathrm{O}_{2}\right)$, superoxide anion $\left(\mathrm{O}_{2}^{-}\right)$, hydrogen peroxide $\left(\mathrm{H}_{2} \mathrm{O}_{2}\right)$ and hydroxyl radical $(\bullet \mathrm{OH})$ in plants, which induce the oxidative stress in plants. In other study, Shalata and Tal (1998) reported that plants have antioxidant systems to respond the oxidative stress by increasing ASA content to protect plants from the oxidative stress. In fact, concentration of ASA in spinach shoots was enriched by the treatment with a root temperature regime of $30^{\circ} \mathrm{C} / 10^{\circ} \mathrm{C}$. Therefore it is considered that the enrichment of ASA concentration was induced to protect plants from the temperature stresses brought with the pretreatment with a high temperature of $30^{\circ} \mathrm{C}$ and the moderately low root temperature of $10^{\circ} \mathrm{C}$. Furthermore, superoxide dismutase (SOD) is an antioxidant enzyme, which is classified into three isozymes such as Fe-SOD, CuZn-SOD and Mn-SOD. Tsang et al. (1991) reported that SOD activity was strongly induced by heat stress in Nicotiana plumbaginifolia where CuZn-SOD appears to be the most responsive of the SOD to heat stress. In other studies, it was reported that the Fe-SOD activity was increased by the environmental stresses in rice plants (Yamane et al., 2004) and spinach (Tanaka et al., 1990). This suggests that the moderately low root temperature of $10^{\circ} \mathrm{C}$ subsequent to the pre-treatment with a high temperature of $30^{\circ} \mathrm{C}$ increased SOD activation where the enriched $\mathrm{Fe}-\mathrm{SOD}$ resulted in the high concentration of $\mathrm{Fe}^{2+}$ in the shoots.

Figure 7 shows time courses of concentrations of $\mathrm{NO}_{3}^{-}$and oxalic acid in spinach shoots treated with the four different root temperature regimes. $\mathrm{NO}_{3}^{-}$and oxalic acid are harmful substances for human health, and concentrations of these harmful substances were remarkably decreased in the treatment with a root temperature regime of $30^{\circ} \mathrm{C} / 10^{\circ} \mathrm{C}$. Cumbus and Nye (1982) reported that shortage of nitrogen in the shoots was occurred when plants were grown at low root temperature, and this shortage was considered to be caused by reductions in shoot demand and root uptake under the low temperature. Under the low temperature stress, the root hydraulic conductance was decreased, which reduced water and nutrient uptake (Fennell and Markhart, 1998). In other study, Affan et al. (2005) reported that the high temperature treatment of tomato plants for two weeks induced root browning and reduction in uptake of nutrients $\left(\mathrm{NO}_{3}^{-}, \mathrm{Ca}^{2+}\right.$ etc.). In this study, the root browning was also found in spinach five days after the start of the pre-treatment 

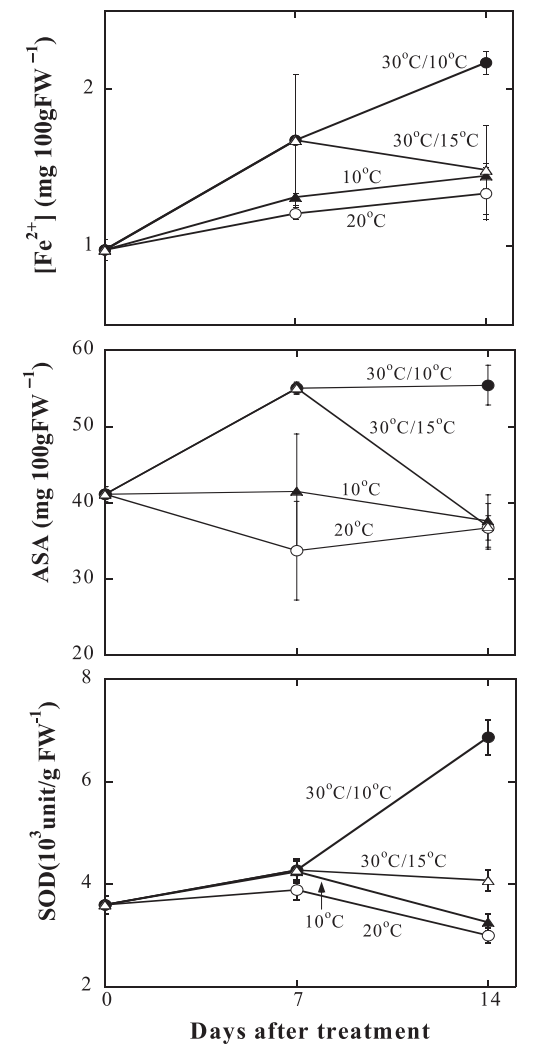

Fig. 6 Time courses of concentrations of $\mathrm{Fe}^{2+}$, ascorbic acid (ASA) and SOD activity in the shoot of spinach plants treated with the four different regimes of root temperature during two weeks before the harvest. Symbols are explained in Fig. 2.

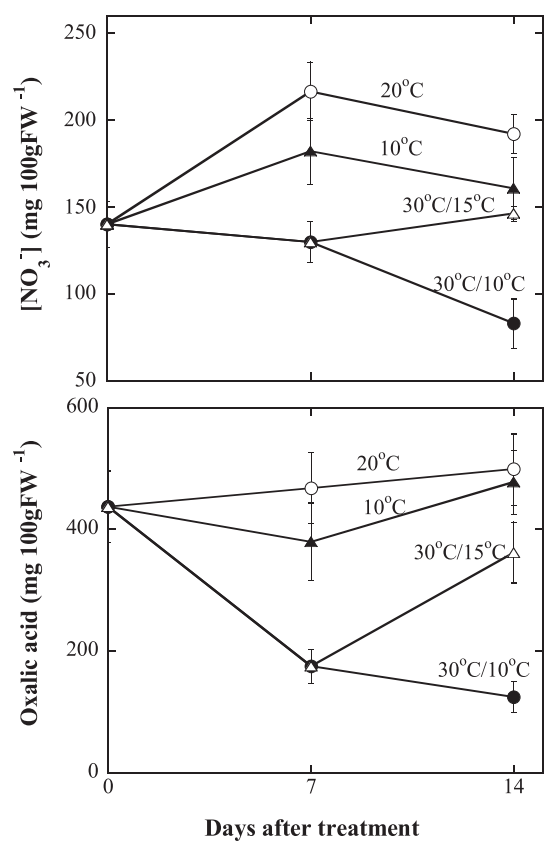

Fig. 7 Time courses of concentrations of $\mathrm{NO}_{3}^{-}$and oxalic acid in the shoot of spinach plants treated with the four different regimes of root temperature during two weeks before the harvest. Symbols are explained in Fig. 2.

with a high root temperature of $30^{\circ} \mathrm{C}$. Thus it is suggested that one week of high temperature treatment of $30^{\circ} \mathrm{C}$ to spinach roots was too long caused physiological damage of roots. Moreover, Libert and Franceschi (1987) reported high levels of calcium uptake enhanced oxalate accumulation in oxalate accumulating plants. From these facts, it is suggested that the high root temperature pre-treatment for a week and the subsequent treatment with the moderately low root temperature reduced uptake of $\mathrm{NO}_{3}^{-}$and $\mathrm{Ca}^{2+}$ and these reductions resulted in reduction of $\mathrm{NO}_{3}^{-}$and oxalate in spinach shoots.

Plants have the capability to adapt to environmental stresses (e.g. temperature stress, water stress, salt stress), which can induce adaptive functions in plants such as osmoregulation and antioxidation. The optimum temperature for healthy growth of spinach plants is around $20^{\circ} \mathrm{C}$, and therefore the treatments with root temperatures of $10^{\circ} \mathrm{C}$ and $30^{\circ} \mathrm{C}$ can be expected to induce the moderate stress for low and high temperatures, respectively. In this study, the one week treatment with a moderately low root temperature of $10^{\circ} \mathrm{C}$ subsequent to the one week pre-treatment with a moderately high root temperature of $30^{\circ} \mathrm{C}$ induced absorption depression in roots and adaptive functions of osmoregulation and antioxidation in shoots responding to the moderate temperature stresses, while the two weeks treatment only with a moderately low root temperature of $10^{\circ} \mathrm{C}$ 


\section{Y. CHADIRIN ET AL.}

induced no significant functions of osmoregulation and antioxidation. The absorption depression in roots and adaptive functions of osmoregulation and antioxidation induced by the combination of the one week pre-treatment with a moderately high root temperature of $30^{\circ} \mathrm{C}$ and the one week treatment with a moderately low root temperature of $10^{\circ} \mathrm{C}$ enabled to produce value-added spinach shoots with high content of healthful substances such as sugars, $\mathrm{Fe}^{2+}$, ASA and SOD (Figs. 5 and 6) and with low content of harmful substances such as $\mathrm{NO}_{3}^{-}$and oxalic acid (Fig. 7). However, the one week pretreatment with $30^{\circ} \mathrm{C}$ and the subsequent one week treatment with $10^{\circ} \mathrm{C}$ caused significant depression in leaf expansive growth (Figs. 3 and 4), and this result implies the possibility that the term of one week for the respective treatments with high and low temperature stresses was too long for the sound growth of spinach plants. Thus, the combination treatment with a moderately high root temperature of $30^{\circ} \mathrm{C}$ and a moderately low root temperature of $10^{\circ} \mathrm{C}$ should be more examined to optimize the terms of the respective treatments for producing value-added spinach without significant growth depression.

This research was supported by Grants-in-Aid for Scientific Research (No.23380150) from the Japan Society for the Promotion of Science.

\section{REFERENCES}

Affan, M. F. F., Wajima, T., Yasutake, D., Hidaka, K., Kitano, M. 2005. High temperature effect on root absorption. J. Agric. Meteorol. 60: 809-812.

Asada, K. 1999. The water-water cycle in chloroplasts: Scavenging of active oxygens and dissipation of excess photons. Annu. Rev. Plant Physiol. Plant Mol. Biol. 50: 601-639.

Cumbus, I. P., Nye, P. H. 1982. Root zone temperature effects on growth and nitrate absorption in rape (Brussica napus cv. Emerald). J. Exp. Bot. 33: 1138-1146.

Fennell, A., Markhart, A. H. 1998. Rapid acclimation of root hydraulic conductivity to low temperature. J. Exp. Bot. 49: 879-884.

Hidaka, K., Yasutake, D., Kitano, M., Takahashi, T., Sago, Y., Ishikawa, K., Kawano, T. 2008. Production of high quality vegetable by applying low temperature stress to roots. Acta Hort. 801: 1431-1436.

Kitano, M., Hidaka, K., Zushi, K., Araki, T. 2008. Production of value-added vegetables by applying environmental stresses to roots in soilles culture. J.SHITA 20: 210-218.

Libert, B., Franceschi, V. R. 1987. Oxalate in crop plants. J. Agric. Food Chem. 35: 926-938.

Lokhande, S. D., Ogawa, K., Tanaka, A., Hara, T. 2003. Effect of temperature on ascorbate peroxidase activity and flowering of Arabidopsis thaliana ecotypes under different light conditions. Plant Physiol. 160: 57-64.

Shalata, A., Tal, M. 1998. The effect of salt stress on lipid peroxidation and antioxidants in the leaf of the cultivated tomato and its wild salt-tolerant relative Lycopersicon pennellii. Physiol. Plant. 104: 169-174.

Tahir, I. S. A., Nakata, N., Yamaguchi, T., Nakano, J., Ali, A. M. 2008. Influence of high shoot and rootzone temperature on growth of three wheat genotypes during early vegetative stages. J. Agron. Crop Sci. 194: $141-151$.

Tanaka, K., Masuda, R., Sugimoto, T. 1990. Water deficiency-induced changes in the contents of defensive substances against active oxygen in spinach leaves. Agric. Biol. Chem. 50: 2629-2634.

Tsang, E. W. T., Bowler, C., Herouart, D., Camp, van W., Villarroel, R., Genetello, C., Montagu, van M., Inze, D. 1991. Differential regulation of superoxide dismutases in plants exposed to environmental stress. Plant Cell 3: 783-792.

Ukeda, H. 2001. Novel assay methods of enzyme superoxide dismutase (SOD). Nippon Nogeikagaku Kaishi 75: $562-565$.

Wan, X., Landhäusser, S., Zwiazek, J. J., Lieffers, V. J. 1999. Root water flow and growth of aspen (Populus tremuloides) at low root temperatures. Tree Physiol. 19: 879-884.

Yamane, K., Rahman, M. S., Kawasaki, M., Tanihuchi, M., Miyake, H. 2004. Pretreatment with antioxidants decreases the effects of salts stress on chloroplast ultrastructure in rice leaf segments (Oryza sativa L.). Plant Prod. Sci. 7: 292-300. 